\title{
Wheeler's dilemma revisited: first Oecophylla-Lasius syninclusion and other ants syninclusions in the Bitterfeld amber (late Eocene)
}

\author{
A.G. Radchenko', E.E. Perkovsky ${ }^{1,2}$ \\ ${ }^{1}$ I.I. Schmalhausen Institute of Zoology, NAS of Ukraine, B. Khmelnitskogo str., 15, Kiev, 01030, \\ Ukraine.E-mails: agradchenko@hotmail.com,perkovsk@gmail.com \\ ${ }^{2}$ A.A. Borissiak Paleontological Institute, Russian Academy of Sciences, Profsoyuznaya Str. 123, \\ Moscow, 117868 Russia.
}

ABSTRACT. The first syninclusions of extant tropical and Holarctic ant genera are reported from Bitterfeld amber: the tropical Oecophylla F. Smith (O. brischkei Mayr, 1868) with the Holarctic genus Lasius F. (four workers of L. schiefferdeckeri Mayr, 1868), and others. The ratio of tropical and Holarctic ants in Bitterfeld, Baltic, Rovno and Danish ambers is analyzed; Holarctic ants dominate in all ambers, consistent with late Eocene climate. Oecophylla, Lasius and the temperate extant Palaearctic caddisfly genus Beraeodes Eaton are dominant as compression fossils in the terminal Eocene Bembridge Marls, UK. Syninclusions of Oecophylla with Lasius, as well as syninclusions of Beraeodes with Yantaromyrmex Dlussky et Dubovikoff, 2013 in Rovno amber, are consistent with an equable climate of the late Eocene amber forests of Europe. The cooccurrence of Oecophylla, Lasius and Beraeodes at the terminal Eocene in the Bembridge Marls supports a late Eocene age of European ambers. The coexistence of Oecophylla and Lasius in Europe was possible only from the late Eocene to the late Miocene: until the late Eocene, the climate in European middle latitudes was too hot for aphids, the obligate symbionts of Lasius, but after the late Miocene it became too cold for Oecophylla. The dominance of Oecophylla in the periodically flooded terminal Eocene Bembridge environment might be explained by its arboreal lifestyle providing a competitive advantage over terrestrial Formica species, for which nesting places were quite limited under these conditions.

How to cite this article: Radchenko A.G., Perkovsky E.E. 2021. Wheeler's dilemma revisited: first Oecophylla-Lasius syninclusion and other ants syninclusions in the Bitterfeld amber (late Eocene) // Invert. Zool. Vol.18. No.1. P.47-65. doi: 10.15298/invertzool.18.1.05

KEY WORDS: age of Baltic amber, Priabonian, paleoclimate, Europe, palaeontology, Bembridge, Formica, Beraeodes. 


\title{
Возвращение к дилемме Вилера: первый сининклюз Oecophylla и Lasius и другие сининклюзы муравьёв в саксонском янтаре
}

\author{
А.Г. Радченко', Е.Э. Перковский ${ }^{1,2}$ \\ ${ }^{1}$ Институт зоологии им. И. И. Шмальгаузена НАН Украины, ул. Б. Хмельницкого, 15, Киев, \\ 01030, Украина.E-mails: agradchenko@hotmail.com,perkovsk@gmail.com \\ 2 Палеонтологический институт им. А.А. Борисяка РАН, Профсоюзная ул. 123, Москва \\ 117997, Россия.
}

РЕЗЮМЕ. Впервые приведены сведения о сининклюзах современных тропических и голарктических родов муравьев из саксонского янтаря: тропического Oecophylla F. Smith (рабочий O. brischkei Mayr, 1868) с голарктическим Lasius F. (четыре рабочих L. schiefferdeckeri Mayr, 1868), а также из других родов. Проанализировано соотношение тропических и голарктических муравьев в саксонском, балтийском, ровенском и датском янтарях; голарктические муравьи доминируют во всех янтарях, что соответствует климату позднего эоцена. Oecophylla, Lasius и ныне живущий в палеарктических регионах с умеренным климатом род ручейников Beraeodes Eaton доминируют в отпечатках из терминального эоцена Бембриджа, Великобритания. Сининклюзы Oecophylla c Lasius, а также Beraeodes с Yantaromyrmex Dlussky et Dubovikoff, 2013 в ровенском янтаре говорит об эквабельном климате янтарных лесов Европы в позднем эоцене. Совместное обитание Oecophylla, Lasius и Beraeodes в Бембридже также свидетельствует в пользу позднеэоценового возраста европейских янтарей. Сосуществование Oecophylla и Lasius в Европе было возможным только с позднего эоцена до позднего миоцена: до позднего эоцена климат в европейских средних широтах был слишком жарким для тлей, облигатных симбионтов Lasius, но после позднего миоцена стал слишком холодным для Oecophylla. Преобладание Oecophylla в периодически затопляемых местообитаниях Бембриджа в самом конце эоцена может быть объяснено древесным образом жизни экофилл, обеспечивающим конкурентные преимущества перед наземными видами Formica, места для гнездования которых в этих условиях были весьма ограничены.

Как цитировать эту статью: Radchenko A.G., Perkovsky E.E. 2021. Wheeler's dilemma revisited: first Oecophylla-Lasius syninclusion and other ants syninclusions in the Bitterfeld amber(late Eocene)//Invert. Zool. Vol.18. No.1.P.47-65. doi: 10.15298/invertzool.18.1.05

КЛЮЧЕВЫЕ СЛОВА: возраст балтийского янтаря, приабон, палеоклимат, Европа, палеонтология, Бембридж, Formica, Beraeodes. 


\section{Introduction}

More than century ago Wheeler (1910) drew attention to the unusual mixed character of the ant fauna of Baltic amber, which includes both modern temperate and tropical genera. He later divided the amber ant genera into two groups: "those which are today represented in Europe and Siberia and those either belonging to the Indomalayan and Australian fauna, or with more or less pronounced affinities to this latter fauna... we are able to recognize at least four different faunas, the palearctic, the Indian, the Malayan and the Australian" (Wheeler, 1915: 12). Such a combination of temperate ("Holarctic" according Dlussky, Rasnitsyn, 2009; Perkovsky, 2011a, 2016) and tropical genera in the same habitats is not known today.

Wheeler (1915) proposed two hypotheses to explain these cooccurrences: 1) the amber was created over a long interval during the late Eocene, and tropical ant genera existed there earlier, when the climate was warmer, and temperate ones later, after the climate cooled; 2) the amber has the same geological age, but the tropical genera lived in hot lowlands and temperate ones in cooler regional uplands, from where resin was carried down by streams and then redeposited on the same territory as "lowland" resin. Both hypotheses are rejected now.

The second hypothesis assumes the presence of rather high mountains in the places where amber forests grow. However, such regional mountains at that time were only in Scandinavia, and these were much lower than now, as their secondary uplift wasn't until the Neogene (Ollier, Pain, 2019). Daley (1972), examining this climatic mixture in the late Eocene flora of southern England, rejected the two elevations hypothesis as such mountains would have had to exceeded $2000 \mathrm{~m}$ above sea level, incompatible with paleotopographic reconstructions.

Daley (1972) hypothesized a late Eocene central and northern European climate with no present day analogue. Late Eocene global mean annual temperatures (MAT) were around $5{ }^{\circ} \mathrm{C}$ warmer than today (Westerhold et al., 2020).
The climate had much less seasonal temperature fluctuation, lacking winter frost, rainfall was higher than that of today, and MAT were higher, though not as high as those in modern tropical rain forests (Daley, 1972). Archibald \& Farrell (2003) called such climate "more equable", i.e., not completely seasonless, but with reduced thermal seasonality compare to modern temperate regions, with higher mean temperature of cold months allowing plant and animal taxa excluded from extra-tropical regions today by cold winters, not by lack of heat, to extend their ranges into milder mid-latitudes.

The hypotheses that the amber was formed in the same place at different geological times or at different elevations are refuted by the cooccurrences (syninclusions) of insects and other invertebrates in the same piece of amber. The term syninclusions was proposed by Koteja (1989), who proposed their usefulness as an instrument of scientific inquiry. Syninclusion analysis has come to be widely used by paleobiologists as a key means for studying the structure of the biocenoses of ancient amber forests (Kutscher, Koteja, 2000; Sontag, 2003; Perrichot, Girard, 2009; Weitschat, 2009; Wichard, 2009; Coty et al., 2014). We have widely used this approach, especially in the study of anthomopteran syninclusions first from Rovno amber, then from Bitterfeld, Baltic and Danish ambers (Perkovsky et al., 2007, 2010, 2012; Perkovsky, 2006, 2007a, b, 2008a, b, 2009a, b, 2010, 2011b, 2013a).

\section{Material and Methods}

We investigated ants from Bitterfeld amber from the collection of Zoological Museum of Humboldt University, Berlin, and collection of Mr. Manfred Kutscher, Sassnitz, Rügen, Germany, preserved at the Geowissenschaftlicher Zentrum der Georg-August-Universität Göttingen. Detailed data on these ant collections are given by Dlussky \& Rasnitsyn (2009).

The original photographs were taken with Leica Z16 APO stereomicroscope equipped with Leica DFC 450 camera and processed by LAS Core software (E.V. Martynova) and Leica 
M165C stereomicroscope equipped with Leica DFC 420 camera and processed by LAS Core software (A.P. Rasnitsyn).

\section{Results}

Thirty-five of the 68 ant genera known from the late Eocene European ambers are extant, and 17 of 41 (Dubovikoff et al., 2020) are extinct in Bitterfeld amber (61 species, all are extinct). The characterization of ants in Baltic, Rovno, Bitterfeld and Danish ambers as Holarctic or tropical was partially considered by Dlussky \& Rasnitsyn (2009) and Perkovsky (2011a, 2016).

The extant ant genera and species groups found in Bitterfeld amber that we classed as Holarctic are (number of species in species group in parentheses): Formica Linnaeus, 1758, Lasius Fabricius, 1804, Camponotus mengei Mayr, 1858, Prenolepis Mayr, 1861, Plagiolepis pygmaea species-group (three) (Formicinae), Dolichoderus quadripunctatus speciesgroup (two) (Dolichoderinae), Aphaenogaster Mayr, 1853, Temnothorax Mayr, 1861, Myrmica Latreille, 1804 (Myrmicinae).

We grouped the following extant genera or species-groups as tropical: Gesomyrmex Mayr, 1868, Oecophylla F. Smith, 1869, Pseudolasius Emery, 1887 (Formicinae), Tapinoma Foerster, 1850, Technomyrmex Mayr, 1872, Dolichoderus thoracicus species-group, D. scabridus, D. cuspidatus, and D. sulcaticeps species-groups (Dolichoderinae), Carebara Westwood, 1840, Pristomyrmex Mayr 1866 (Myrmicinae), Tetraponera F. Smith, 1852 (Pseudomyrmecinae), Gnamptogenys Roger, 1863 (Ectatomminae), Pachycondyla F. Smith, 1858 (Ponerinae).

Temnothorax is among the most speciose extant ant genera, comprising more than 400 species today, distributed worldwide except for Australia, most of which are Holarctic. Only six species are known from the Afrotropical Region, all belonging to the Mediterranean species groups (Prebus, 2015); Temnothorax species inhabit southern China, the Himalayas and in northern mountains of Vietnam and Myanmar; though they are very diverse in Central Ameri- ca, they do not penetrate into South America except in the extreme north-western edge of Columbia (Prebus, 2017). Temnothorax species are nearly absent in the vast Eurasian taiga (except in the southern Russian Far East). They are found north to southern Sweden and Finland, and are most diverse and abundant in much warmer deciduous and mixed forests, and in regions of Mediterranean vegetation from the Atlantic to Central Asia. They generally avoid true deserts. Therefore, Palaearctic Temnothorax species are characterized as mesophylic or meso-thermophilic dwellers of various types of warm forests or open landscapes. They nest in soil, under stones, in rock crevices, leaf litter, and many are typically arboreal.

Six fossil Temnothorax species have been previously described in Baltic amber (see Wheeler, 1915), and at least 10 new species have not yet been described in Baltic and other late Eocene European ambers (Radchenko, unpublished data). All of these belong to, or are at least potentially related to extant species from various Palaearctic species-groups of the genus, but in any case they are not more closely related to the Central America species. Therefore, here we consider Temnothorax species from European ambers to be Holarctic.

Camponotus Mayr, 1861 is one of the most diverse of ant genera, with more than 1000 species, second only to Pheidole Westwood, 1839 (Bolton, 2020). It has a worldwide distribution (except Antarctica), both in the Temperate Zone and in the tropics. Nevertheless, only one described species, C. mengei, is known from all late Eocene European ambers. Mayr (1868) assumed that it is related to extant $C$. sylvaticus (Olivier, 1792) from the subgenus Tanaemyrmex Ashmead, 1905 distributed in South Europe, but Wheeler (1915) questioned this. We agree with Wheeler and suppose that $C$. mengei, by the shape of the head, mesosoma and especially clypeus, more closely resembles species of the modern subgenus Camponotus s.str., which are distributed in the Holarctic Subboreal Zone.

The genus Aphaenogaster includes more than 200 extant species, distributed in the south- 
ern Palaearctic, the Oriental Region, Australia, the Nearctic, the Neotropics (Mexico and Central America), and Madagascar, but it is absent in the Afrotropical Region. About half of them are known from the Palaearctic. More than 20 fossil species were previously attributed to this genus, but Radchenko and Perkovsky (2016) reduced this number to nine, and proposed to transfer the other eleven to the morphogenus Paraphaenogaster Dlussky, 1981. Recently, Jessen (2020) described a further Aphaenogaster species from the late Oligocene deposits of Enspel (Germany). All of these Aphaenogaster fossils were found in Eurasia and America, mostly from the late Eocene (European ambers and Florissant) and middle Miocene (Dominican and Mexican ambers). The oldest described Aphaenogaster (and oldest described Myrmicinae species) is from middle Eocene Sakhalinian amber (Radchenko, Perkovsky, 2016). All Aphaenogaster species from late Eocene European ambers and Florissant (latest Eocene) are similar to those of the extant Holarctic former subgenus Attomyrma Emery, 1915 (Radchenko, Perkovsky, 2016), and so we consider the European amber Aphaenogaster species Holarctic.

In the generic revision of modern Ponerinae (Schmidt, Shattuck, 2014), the taxonomic status of Pachycondyla was reassessed and many generic names were restored from synonymy. As a result, Pachycondyla is now considered Neotropical with some species in the southern $\mathrm{Ne}$ arctic. The taxonomic position of all fossil species previously attributed to Pachycondyla (Dlussky, 2009; see also Schmidt, Shattuck, 2014) need thorough revision.

The cosmopolitan genus Tapinoma has more than 70 extant species, 17 of which are distributed in the Palaearctic, and only two in the Nearctic. Two fossil species described from late Eocene European ambers are close to modern Oriental species (Dlussky, Perkovsky, 2002; Dubovikoff, 2012), and we consider amber Tapinoma tropical.

We find it somewhat difficult to attribute extinct amber species of the extant genera $\mathrm{Ny}$ landeria Emery, 1906, Ponera Latreille, 1804,
Hypoponera Santschi, 1938 and Monomorium Mayr, 1855 as well as two Plagiolepis Mayr, 1861 species, to Holarctic or tropical groups for the following reasons.

Nylanderia is cosmopolitan, with 125 extant and two extinct species: N. pygmaea (Mayr, 1868) from late Eocene European ambers, and one from Miocene Dominican amber. Most of its extant species are distributed in tropical regions; some are typical tramp species, introduced to all continents. Seventeen native species are known from the Nearctic and five from the Palaearctic (North Africa, Transcaucasia, the Middle East, China, Korea, and Japan), but no native Nylanderia species are known from Europe (Pisarski, 1960; LaPolla et al., 2010; LaPolla, Dlussky, 2010; Kallal, LaPolla, 2012; Messer et al., 2016; Bolton, 2020). Since the internal phylogeny of Nylanderia has not yet been examined, it is difficult to characterize $N$. pygmaea as tropical or Holarctic, only that it is not related to extant Nearctic species-groups. However, the ecological preferences of most modern tropical species appear analogous to that of $N$. pygmaea in the amber forests. Based on this assumption as well by zoogeographic data, we place $N$. pygmaea in the tropical group.

Hypoponera is one of the most diverse ponerine genera, with more than 150 described extant species, but there may be many more. They are distributed predominately in all tropical regions, but eight native species are found in the Palaearctic (four in the Mediterranean Region from the Atlantic to the Transcaucasia, and four in China, Korea and Japan), and one in the Nearctic (Schmidt, Shattuck, 2014). Its single known fossil species, H. atavia (Mayr, 1868), is one of 19 ant species found in all late Eocene European ambers (Perkovsky, 2016). Its affinities to modern species remain unknown, but we tentatively place it in the tropical group.

The genus Ponera presents a similar situation. It currently has 60 extant species, mostly distributed in the Oriental Region and Australia, but absent in the Afrotropical and Malagasy Regions and in the Neotropics (but some species penetrating Central America from the north). Only six species are known in the Palaearctic 
(three from Europe, the Mediterranean Region, the Near East and Transcaucasia, and three from China, Korea and Japan), and two species from the Nearctic. Three species from late Eocene European ambers were recently described by Dlussky (2009) based exclusively on males. Nothing can be said about the relationship of these fossil species to extant species, but by analogy with Hypoponera, we propose to consider them as tropical.

Dlussky (2010) attributed Plagiolepis species from late Eocene European ambers to two species-groups: the modern Palaearctic pygmaea-group (we considered them Holarctic, see above), and the extinct klinsmanni speciesgroup. Members of the latter group are characterized by their nodiform petiole, unique among all known Plagiolepis species. Most likely they represent an extinct specialized branch of the genus, adapted to conditions of the amber forests, and we doubt they can be assigned to either the tropical or Holarctic groups.

Monomorium is among the most speciose of myrmicine genera, with more than 300 extant species (Bolton, 2020). Its greatest diversity occurs in the Afrotropical and Malagasy Regions (more than half of known species), and in Australia; they are also abundant in the Oriental Region, as well in the southern, semiarid, arid and subtropical parts of Palaearctic (about 50 species are recorded from here, see Radchenko, 2016), but their Neotropical and Nearctic faunas are much less diverse (Bolton, 1987). Three extinct species were described from late Eocene European ambers (Radchenko, Perkovsky, 2009), two of them among the most common amber ants. Nevertheless, it is impossible at this time to make a definitive conclusion on the relatedness of these species with any modern ones, and so we cannot attribute any of them to either the "Holarctic" or "tropical" group.

It is often much more difficult or even impossible to classify extinct amber genera as tropical or Holarctic.

Nevertheless, Dlussky \& Rasnitsyn (2009) and Perkovsky (2011a, 2016) provided justifications for including the genera Yantaromyrmex Dlussky et Dubovikoff, 2013 (Dolichoderinae),
Procerapachys Wheeler, 1915 (Dorylinae), Paraneuretus Wheeler, 1915, Protaneuretus Wheeler, 1915 (Aneuretinae), Prionomyrmex Mayr, 1868 (Myrmeciinae), Fallomyrma Dlussky et Radchenko, 2006 (Myrmicinae) and Bradoponera Mayr, 1868 (Proceratiinae) in the tropical group.

Here we consider the genera Conoformica Dlussky, 2008 (Formicinae) and Eocenomyrma Dlussky et Radchenko, 2006 (Myrmicinae) as Holarctic by the following reasons: Conoformica belongs to the tribe Formicini, all extant members of which are distributed almost exclusively in the Holarctic (Dlussky, 2008), and Eocenomyrma is related to the genus Temnothorax (Radchenko, Dlussky, 2016).

Finally, we find it difficult to attribute fossil Ctenobethylus Brues, 1939, Eldermyrmex Shattuck, 2011, Zherichinius Dlussky, 1988 (Dolichoderinae), Electromyrmex Wheeler, 1915, Enneamerus Mayr, 1868, Stigmomyrmex Mayr, 1868 and Plesiomyrmex Dlussky et Radchenko, 2009 to either groups.

As above, the study of ant (and other invertebrate) syninclusions is very important for analyses of the taxonomic and ecological structures of amber faunas, and are especially important in understanding their implications as tropical and Holarctic taxa.

Already Wheeler (1915) reported 10 ant syninclusions from Baltic amber and stressed that "simultaneous inclusion could only have occurred in the case of forms living at precisely the same time and place" (op. cit.: 15). Though they did not include a mix of definitely tropical and Holarctic ant genera, five syninclusions with Ctenobethylus goepperti (Mayr, 1868) contain Holarctic Dolichoderus tertiarius (Mayr, 1868), Myrmica rudis (Mayr, 1868), Lasius schiefferdeckeri Mayr, 1868, Formica flori Mayr, 1868 and Cataglyphoides constrictus (Mayr, 1868), while two other include C. goepperti with tropical Yantaromyrmex geinitzi (Mayr, 1868) and Gesomyrmex hoernesi Mayr, 1868 (names of species and genera are given according to modern taxonomy). The remaining three syninclusions contain only Holarctic or only tropical genera. 
Table 1. Ant syninclusions in Bitterfeld amber. Таблица 1. Сининклюзы муравьёв в саксонском янтаре.

\begin{tabular}{|c|c|c|c|c|}
\hline Museums, numbers & Species & $\begin{array}{c}\text { Castes, } \\
\text { specimens }\end{array}$ & Species & $\begin{array}{c}\text { Castes, } \\
\text { specimens }\end{array}$ \\
\hline HMB 7/235 & $\begin{array}{l}\text { Ctenobethylus } \\
\text { goepperti }\end{array}$ & $1 \mathrm{w}$ & $\begin{array}{l}\text { Lasius } \\
\text { schiefferdeckeri }\end{array}$ & $1 \mathrm{w}$ \\
\hline HMB 10/205 & $\begin{array}{l}\text { Ctenobethylus } \\
\text { goepperti }\end{array}$ & $1 \mathrm{w}$ & $\begin{array}{l}\text { Lasius } \\
\text { schiefferdeckeri }\end{array}$ & $1 \mathrm{w}$ \\
\hline HMB 12/201 & $\begin{array}{l}\text { Yantaromyrmex } \\
\text { geinitzi }\end{array}$ & $1 \mathrm{w}$ & $\begin{array}{l}\text { Temnothorax } \\
\text { gracilis }\end{array}$ & $1 \mathrm{~g}, 1 \mathrm{~m}$ \\
\hline HMB 12/225 & Myrmica sp.n. & $1 \mathrm{w}$ & $\begin{array}{l}\text { Plagiolepis } \\
\text { kuenowi }\end{array}$ & $1 \mathrm{w}$ \\
\hline HMB 12/227 & Temnothorax sp.n. & $1 \mathrm{w}$ & $\begin{array}{l}\text { Yantaromyrmex } \\
\text { geinitzi }\end{array}$ & $2 w$ \\
\hline HMB 14/208 & Monomorium pilipes & $1 \mathrm{w}$ & $\begin{array}{l}\text { Tapinoma } \\
\text { electrinum }\end{array}$ & $1 \mathrm{w}$ \\
\hline HMB 14/211 & Formica flori & $1 \mathrm{w}$ & $\begin{array}{l}\text { Lasius } \\
\text { schiefferdeckeri }\end{array}$ & $1 \mathrm{w}$ \\
\hline HMB 15/222 & Formica flori & $1 \mathrm{w}$ & $\begin{array}{l}\text { Monomorium } \\
\text { mayrianum }\end{array}$ & $1 \mathrm{w}$ \\
\hline HMB 16/215 & $\begin{array}{l}\text { Ctenobethylus } \\
\text { goepperti }\end{array}$ & $1 \mathrm{w}$ & $\begin{array}{l}\text { Monomorium } \\
\text { mayrianum }\end{array}$ & $1 \mathrm{w}$ \\
\hline HMB 16/266 & $\begin{array}{l}\text { Ctenobethylus } \\
\text { goepperti }\end{array}$ & $1 \mathrm{w}$ & $\begin{array}{l}\text { Plagiolepis } \\
\text { squamifera }\end{array}$ & $1 \mathrm{w}$ \\
\hline HMB 7/235 & $\begin{array}{l}\text { Ctenobethylus } \\
\text { goepperti }\end{array}$ & $1 \mathrm{w}$ & $\begin{array}{l}\text { Lasius } \\
\text { schiefferdeckeri }\end{array}$ & $1 \mathrm{w}$ \\
\hline GZG.BST.27.016 & $\begin{array}{l}\text { Gnamptogenys } \\
\text { europea }\end{array}$ & $1 \mathrm{~m}$ & $\begin{array}{l}\text { Nylanderia } \\
\text { pygmaea }\end{array}$ & $6 \mathrm{~m}$ \\
\hline GZG.BST.27.040 & $\begin{array}{l}\text { Ctenobethylus } \\
\text { goepperti }\end{array}$ & $1 \mathrm{w}$ & $\begin{array}{l}\text { Nylanderia } \\
\text { pygmaea }\end{array}$ & $5 \mathrm{~m}$ \\
\hline GZG.BST.27.053 & Formica flori & $1 \mathrm{w}$ & $\begin{array}{l}\text { Ctenobethylus } \\
\text { goepperti }\end{array}$ & $3 \mathrm{w}$ \\
\hline GZG.BST.27.063 & $\begin{array}{l}\text { Lasius } \\
\text { schiefferdeckeri }\end{array}$ & $4 w$ & $\begin{array}{l}\text { Oecophylla } \\
\text { brischkei }\end{array}$ & $1 \mathrm{w}$ \\
\hline GZG.BST.27.090 & Monomorium pilipes & $1 \mathrm{w}$ & $\begin{array}{l}\text { Yantaromyrmex } \\
\text { geinitzi }\end{array}$ & $1 \mathrm{w}$ \\
\hline GZG.BST.27.101 & Bradoponera meyeri & $1 \mathrm{w}$ & Formica flori & $1 \mathrm{w}$ \\
\hline GZG.BST.27.157 & $\begin{array}{l}\text { Ctenobethylus } \\
\text { goepperti }\end{array}$ & $2 \mathrm{w}$ & $\begin{array}{l}\text { Tetraponera } \\
\text { simplex }\end{array}$ & $1 \mathrm{w}$ \\
\hline
\end{tabular}

More than 60 ant syninclusions are known in late Eocene European ambers, including those with $L$. schiefferdeckeri reported by Dlussky (2011); 20 of these are from Bitterfeld amber (Dlussky, pers. comm., 2013) (Table 1).

Five syninclusions from Bitterfeld amber contain both tropical and Holarctic ants: two of
Y. geinitzi with Temnothorax gracilis (Mayr, 1868), Y. geinitzi with Temnothorax sp. nov., Oecophylla brischkei Mayr, 1868 with L. schiefferdeckeri (Fig. 1), and Bradoponera meyeri Mayr, 1868 with $F$. flori. Two contain only Holarctic species: a $F$. flori with $L$. schiefferdeckeri and Myrmica sp.n. with Plagiolepis 

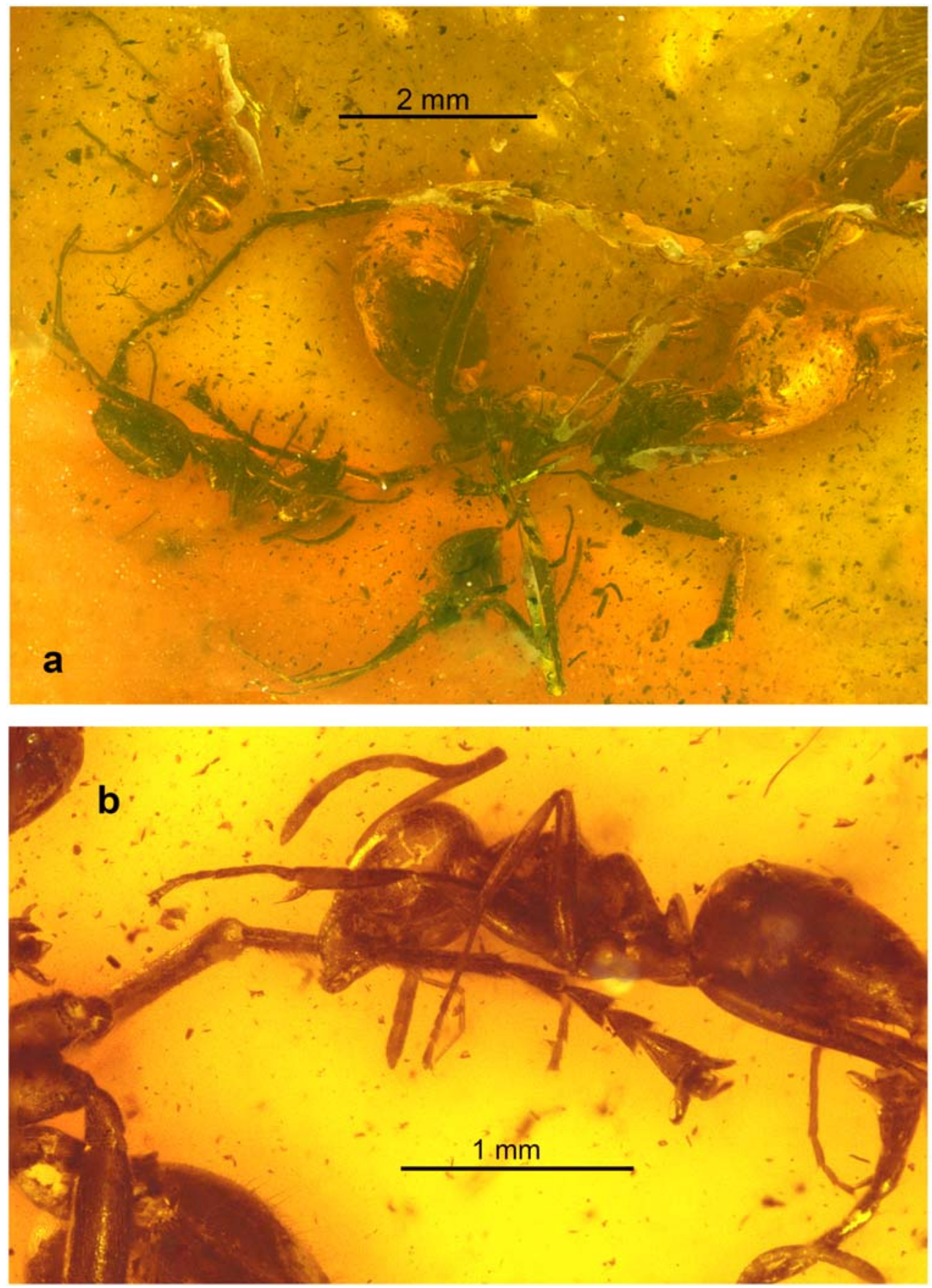

Fig. 1. Photo of syninclusion of Oecophylla brischkei and Lasius schiefferdeckeri; a - general appearance (photo by E.V. Martynova), b - detail, L. schiefferdeckeri, biting leg of Oecophylla (photo by A.P. Rasnitsyn); Bitterfeld amber, No. GZG.BST.27.063a.

Рис. 1. Фото сининклюза Oecophylla brischkei и Lasius schiefferdeckeri; а - общий вид (фото Е.В.Мартыновой), b - деталь, L. schiefferdeckeri, кусающий Oecophylla за ногу (фото А.П. Расницына); саксонский янтарь, No. GZG.BST.27.063a. 
Table 2. Number of specimens of Holarctic and tropical s.l. ants in the representative amber collections. Таблица 2. Число экземпляров голарктических и тропических s.1. муравьёв в репрезентативных янтарных коллекциях.

\begin{tabular}{|l|l|c|c|c|}
\hline \multicolumn{1}{|c|}{ Amber } & Collection & Holarctic & Tropical s.l. & $\begin{array}{c}\text { Holarctic/ } \\
\text { Tropical }\end{array}$ \\
\hline Baltic (Russia) & PIN-964 & $186(41.7 \%)$ & $64(14.4 \%)$ & 2.90 \\
\hline Baltic (Poland) & Giecewicz & $157(36.9 \%)$ & $41(9.6 \%)$ & 3.83 \\
\hline Bitterfeld & HMB & $244(35.4 \%)$ & $111(16.2 \%)$ & 2.21 \\
\hline Danish & ZMUC-S & $142(41 \%)$ & $64(18.5 \%)$ & 2.22 \\
\hline Rovno & SIZK & $457(40 \%)$ & $194(17 \%)$ & 2.36 \\
\hline
\end{tabular}

kuenowi Mayr, 1868. One contains only tropical ants: Gnamptogenys europea (Mayr, 1868) with $N$. pygmaea.

As in the syninclusions with Ctenobethylus reported by Wheeler (1915) (see above), four pieces of amber contain C. goepperti with Holarctic species: three with $L$. schiefferdeckeri and one with $F$. flori, but three include $C$. goepperti with the tropical species $N$. pygmaea, Tetraponera simplex (Mayr, 1868) and Dolichoderus passaloma Wheeler, 1915. Two syninclusions with Monomorium pilipes Mayr, 1868 contain tropical genera: Tapinoma electrinum Dlussky, 2002 and $Y$. geinitzi, and one of $M$. mayrianum Wheeler, 1915 is with $F$. flori and another one is with $C$. goepperti.

Thus, regardless of whether Ctenobethylus and Monomorium are considered Holarctic or tropical, they occur in syninclusions with species of both groups, which not only emphasizes the mixed nature of the amber fauna, giving strong support for the cooccurrence of tropical and Holarctic species at the same time and place, and these syninclusions are no less important than those containing definitely Holarctic and tropical species.

The ratio of Holarctic and tropical taxa is important for a better understanding the climatic conditions in amber forests and the age of amber biota as a whole.

After adding Aphaenogaster, Temnothorax, C. mengei, Eocenomyrma and N. pygmaea the ratio of Holarctic to tropical s.l. elements for representative collections is $2.8-3.5$ for Baltic amber, 1.6 for Danish amber and 2.1 for both Bitterfeld and Rovno ambers (Table 2). It is interesting that at least for two amber faunas with the same (Danish, 1.6) or very similar (Rovno, 1.9) ratios were calculated for biting midges (Ceratopogonidae): predominance of Holarctic biting midges in the representative collections from other ambers is even higher than for Holarctic ants (Perkovsky, 2017).

In the early Eocene at Messel and middle Eocene at Eckfeld, tropical taxa absolutely dominate, nearly as much as in tropical climate Oligocene Sicilian amber (Emery, 1891; Wappler, 2003; Dlussky et al., 2008, 2009; Archibald et al., 2011; Dlussky, 2012; Dlussky, Wedmann, 2012). The prevalence of Holarctic species in all representative amber ant collections is associated with decreasing of temperature in the late Eocene (see below). The ratio of Holarctic and tropical specimens in the former private amber ant collection of M. Kutscher from Bitterfeld amber (now in the collection of Geowissenschaftlicher Zentrum der Georg-AugustUniversität Göttingen) is only 0.98 , but it is highly biased, containing mainly rare and 'exotic' ants (Dlussky, Rasnitsyn, 2009).

\section{Discussion}

Oecophylla-Lasius syninclusion is of great importance, as both genera are widely represented in both amber and compression fossils. Despite modern areas where the ranges of both genera partly overlap in the Himalaya and China, we did not find any records of their coexistence at the same site. The northern limit of Oecophylla smaragdina (Fabricius, 1755) extends to $34.1^{\circ} \mathrm{N}$ in China and $32.7^{\circ} \mathrm{N}$ in India, 
and the vast majority of its records come from sites classified as having tropical climates (Wetterer, 2017). The highest altitudinal records of Oecophylla in the Himalayas reported by different authors vary from 900 (Supriya et al., 2020) to 1200 (Wetterer, 2017) or even to 1150-1450 $\mathrm{m}$ a.s.l. (Collingwood, 1970). At the same time, Lasius s. str. species are distributed in southern China and in the Himalayas at higher altitudes than Oecophylla (Seifert, 2020). Wetterer(2017) suggested that more cold-tolerant Oecophylla populations from higher altitudes with subtropical climates could represent a separate species. It is interesting to note that the modern distribution of $O$. smaragdina in subtropical conditions fits well with the discovery of numerous fossil Oecophylla in European Oligocene and Miocene deposits (Dlussky et al., 2008; Dlussky, Perfilieva, 2014; Perfilieva et al., 2017). In general, 16 fossil Oecophylla species have been reported; as well as in Europe, one species was described from the Miocene of Kenya, and another from the early Eocene of the U.S.A. (Dlussky et al., 2008; Perfilieva et al., 2017).

Close mutualistic relations of not only extant but also extinct Lasius species with aphids and other homopteran insects are well-known: syninclusions of Lasius species with numerous aphids have been reported from Bitterfeld amber (Perkovsky, 2006, 2010). Modern Oecophylla species also actively tend homopterans (Crozier et al., 2010), and one may suppose that fossil ones had similar behavior. In the syninclusion GZG.BST.27.063 (Table 1) we observe for the first time three Lasius schiefferdeckeri workers attacking a worker of Oecophylla brischkei, stretching it spread-eagle, while a fourth bites the antennal funiculus of the Oecophylla (and see Fig. 1). Stellate hairs in the syninclusion (Fig. 1) prove that ants got to the resin in spring. This piece of amber contains wood particles (Fig. 1), so it is likely that there may have been old fissured bark with longirostred aphids on the tree trunk nearby, which may support the idea of competition between mentioned species for honeydew.

It is necessary to discuss in more detail the presumed role of Oecophylla species in ecosys- tems since Priabonian. Dlussky \& Rasnitsyn (2007) suggested that they may be strongly underrepresented in late Eocene European ambers $(0.95 \%$ specimens in the representative collection of Bitterfeld amber and much less in all others). They provided two possible explanations for this.

First, these ants are large, with long legs and would be more rarely trapped in the resin than smaller ants. Oecophylla is arboreal; its workers build nests from living broad-leaved trees, while amber was formed from the resin of conifers, where its workers are very unlikely to be found.

Secondly, while alate specimens of Oecophylla can be dispersed far from nests, they are very large, which may decrease their representation in amber like their workers. The forewings of gynes and males of extant species reach 8-9 $\mathrm{mm}$ in length, and forewings of Bitterfeld amber $O$. brischkei males were even larger (10 $\mathrm{mm})$, similar to those of gynes and males of $O$. megarche Cockerell, 1915 from the UK Bembridge Marls, which have wing lengths of 20-23 and $10-16 \mathrm{~mm}$, respectively (Dlussky, Perfilieva, 2014). So, the chance of their being trapped in resin would be even lower than that of the workers. Only two males of Oecophylla are known from the Baltic amber (Wheeler, 1915) vs. about 60 workers (Dlussky, Rasnitsyn, 2009).

However, the amber was formed in the humid and moderately well-illuminated temperate mixed forests (Sadowski et al., 2017; Kaasalainen et al., 2017) and Oecophylla could use leaves of deciduous trees for nest building. Even when the leaves become dry and detach, these nests remain attached to the branch and continue to function (Lokkers, 1990; Radchenko, personal observations).

Hypotheses explaining the presumed strong underrepresentation of Oecophylla in European ambers of gymnosperm origin are based mostly on their dominance as compression fossils in the Bembridge Marls. At the same time, even in the tropical-climate Oligocene Sicilian amber of angiosperm origin, Oecophylla comprise only $4.9 \%$ of ants (Emery, 1891), even less than in the Miocene compression fossils of Radoboj (7.4\%) (Dlussky, Putyatina, 2014). Oecophylla 
has not yet been found in Danish and Rovno ambers, and as more than 1800 amber ant specimens are now known in Rovno amber (vs. ca 1100 in Bitterfeld amber), it can be assumed that this genus was absent in the Rovno amber forests. Oecophylla is represented by single specimens in all European compression localities except the Bembridge Marls and at Radoboj. It seems especially important that only two specimens of Oecophylla $(0.7 \%$ of 278 ants identified to subfamily level) are known from the localities almost coeval with Bembridge Marls, the Upper Rhine Graben of Kleinkems (BadenWürttemberg, Germany) and at Brunstatt (Alsace, France) taken together (Théobald, 1937), and only a single specimen of Oecophylla has been found in the late Eocene deposits of Kučhlin (Czechia) (Deichmüller, 1881).

Ants form multispecies associations (= ant assemblages) in any habitats, and the structure of these depends to a great extent on their interand intraspecific relations (Demchenko, 1975; Dlussky, 1981b). This is very often based on interspecific competition, and dominant species are usually decisive in setting the structure of these associations (Vepsäläinen, Pisarski, 1982; Reznikova, 1983). Dominant species as a rule have very big colonies with tens or even hundreds of thousands of workers; they have a protected foraging area (often quite large one), high dynamic density on the territory, and are usually aggressive towards other dominants (Zakharov, 1991).

Extant Oecophylla species are typical territorial dominant species in ant assemblages, and absence of other dominant ant species is optimal for them(Hölldobler, 1983). Furthermore, weaver ants are also quite vulnerable in extratropical regions because nests made from leaves of deciduous plants there are less durable and often need repair (Lokkers, 1990). The inability to repair a nest or build a new one due to the low activity of workers or the death larvae in winter can lead to the death of the colony.

The most important competitors of fossil Oecophylla in Europe (other than in the Bembridge Marls) may have been various ant species, but it is difficult to define which of them may have been obligate or facultative territorial dominants. For example, extant Lasius emarginatus (Olivier, 1792) is a facultative dominant in many ant associations (Stukalyuk, 2015, 2017), and one may assume that extinct $L$. schiefferdeckeri might have been so, too. Species of the modern subgenus Formica s. str. are typical territorial dominants, but $F$. flori, one of the most abundant ants in late Eocene European ambers, most probably belongs to the subgenus Serviformica Forel, 1913. Most extant species of this subgenus are subordinate in ant communities, but some are facultative dominants (Stukalyuk, 2015) or obligate territorial dominants like $F$. cinerea Mayr, 1853 (Dlussky, 1965). Another kind of domination in ant associations is "numerical dominance", i.e. dominance not by behavior, but exhibit territorial aggression as numerical dominants with high biomass and so increased frequency of interactions (Segev, Ziv, 2012). Such numerically dominant species have a high foraging efficiency, negatively affecting other species that utilize the same food sources.

Fossil Oecophylla probably consumed the honeydew of aphids and other homopterans as well as the numerous invertebrates which they hunted, and their competitors in amber forests could have been the most numerous ants: $C$. goepperti, Y. geinitzi, probably some Dolichoderus, F. flori (and other Formica species) and L. schiefferdeckeri.

Oecophylla species comprise $69.8 \%$ of ant specimens identified to genus level in the Bembridge Marls, and are at least 4.1 times more common there than Lasius (Dlussky, Perfilieva, 2014). Species of the morphogenus Emplastus Donisthorpe, 1920 make up $7.9 \%$ of all ants determined to the genus level, the most common species, E. gurnetensis (Donisthorpe, 1920), is $5 \%$ of ant specimens, and Dolichoderus species $0.7 \%$. This morphogenus may include species of various dolichoderine genera, particularly Yantaromyrmex and Ctenobethylus (Dlussky, Dubovikoff, 2013; Dlussky, Perfilieva, 2014). The formicine ant Leucotaphus gurnetensis Cockerell, 1915 is the third most abundant species among ants of the Bembridge Marls. It comprises $25 \%$ of all ants identified to the 
species level, but the second species of this genus there, L. donistorpei Dlussky et Perfilieva, 2014, is only a tenth as common as $L$. gurnetensis. The majority of ants in the Bembridge Marls are attributed to the morphogenus Leucotaphus Cockerell, 1915 most probably belong to the genus Lasius (Dlussky, Putyatina, 2014); e.g., L. gurnetensis, which is similar in general appearance to modern species of Lasius s.str. (Dlussky, Perfilieva, 2014).

Formica specimens outnumber those of Oecophylla 17 times at Brunstatt and Kleinkems, Dolichoderus 17.5 times, and Ctenobethylus and Yantaromyrmex taken together 11 times (Théobald, 1937). Formica comprise $20.9 \%$ of all ant specimens determined to species at Radoboj, 2.82 times more than Oecophylla, and Lasius specimens are $49.2 \%$, or 6.65 times more common than Oecophylla specimens. The most common Dolichoderinae specimens are those of Liometopum Mayr, 1861, almost as plentiful as Oecophylla (Dlussky, Putyatina, 2014).

Formica makes up 11-12\% of ants, Dolichoderus 4.7-5\%, L. schiefferdeckeri Mayr 9.5$16.4 \%$, Ctenobethylus and Yantaromyrmex together $60-69 \%$, Oecophylla $0.2-0.5 \%$ in representative amber collections from Kaliningrad Province of Russia (Wheeler, 1915; our unpublished data). In the unbiased collection of Bitterfeld amber Formica comprises only 5.5\%, Dolichoderus $5.3 \%$, L. schiefferdeckeri 22.8\%, Ctenobethylus and Yantaromyrmex together 44.9\%, Oecophylla 0.7\%. Accordingly, there are 22-64 times more Formica specimens than those of Oecophylla and Lasius is 21-73 times more common than Oecophylla in the unbiased amber collections of the Kaliningrad Region; in Bitterfeld amber Formica is eight times more common than Oecophylla and Lasius is 33 times more common than Oecophylla.

The reason for the absence of Formica and the relative rarity of Lasius in the Bembridge Marls could be ecological character of the biotope: wetland elements are abundant in the Bembridge flora and non-wetland elements infrequent (Hayes, Collinson, 2014).

Under conditions of periodic flooding, arboreal ants have an obvious advantage. Hooker
(1994) indicated that by many reasons the best analogue for the Bembridge Marls Limestone Formation is freshwater marsh environments of the Florida Everglades. The upper strata of the Bembridge Limestone Formation is thought to have been deposited 10,000 years earlier (Hooker et al., 2009) than the Insect Beds, where all insects of this Lagerstätte are found (Ross, Self, 2014). If it is true and periodic flooding continued during the formation of Insect Beds, this would well explain the abundance of Oecophylla.

Oecophylla colonies form polycalic systems with one or a few large central nests and several peripheral smaller ones. In the winter, workers from peripheral nests move to central ones, and trees controlled by them show significant consumption even in the tropics. The opposite process occurs with the rising of temperature (Lokkers, 1990); for terminal Eocene of Bembridge it must be more pronounced.

The cold month mean temperature (CMMT) for the northernmost locality of extant Oecophylla in Zhoukou (Henan, China) is $1.3{ }^{\circ} \mathrm{C}$. Sabal palms leaves have been found in the Bembridge Marls above the Insect Beds; CMMT for the northernmost extant locality of palms in the eastern North America (Tripp, Dexter, 2006) equals $6.1^{\circ} \mathrm{C}$. Although palms can be somewhat cold tolerant (Kupryjanowicz et al., 2019 and references therein), their northern distribution is affected by the number of days between the first and last with freezing temperatures to zero (Tripp, Dexter, 2006). We presume that in equable climates the number of such days must be less than in an extant seasonal climate with palms and the same CMMT. We estimate CMMT for the Bembridge Marls as $2-5{ }^{\circ} \mathrm{C}$ (with MAT $13.3^{\circ} \mathrm{C}$, Sheldon et al. (2009)). Even a CMMT of $5{ }^{\circ} \mathrm{C}$ is low for a WMMT (warm month mean temperature) of $21.6^{\circ} \mathrm{C}$, but this corresponds well with an estimated CMMT of $0-3{ }^{\circ} \mathrm{C}$ for a more northern terminal Eocene site east of Iceland in the Norwegian Sea (Eldrett et al., 2009). A WMMT not higher than $24.5^{\circ} \mathrm{C}$ is consistent with the abundance of the caddisfly Beraeodes Eaton (see below), unknown from regions with a WMMT higher than $25^{\circ} \mathrm{C}$; Beraeodes can't 
survive even in shallow running water a temperature higher than $25^{\circ} \mathrm{C}$ (Ivanov, pers. com.). We presume winter activity of Oecophylla was very limited at Bembridge, and that attacks on them by Lasius likely took place on aphid colonies in the spring, when Oecophylla presumably would have been increasing their foraging territory after restricted winter activity.

Colonies of Oecophylla have so-called "noant land" along the borders of their protected area (Lokkers, 1990 and references therein). It is interesting to note that among 63 amber specimens of Oecophylla, only three are known as syninclusions: one described here, one with Gesomyrmex in Baltic amber (our unpublished data), and one with a minor worker of Camponotus (which are common prey of modern Oecophylla), as well as several ant fragments (Wheeler, 1915).

Oecophylla and Lasius as syninclusions (as well as Yantaromyrmex and Beraeodes McLachlan, 1879) are also important for confirming the Priabonian age of European ambers of gymnosperm origin.

Perkovsky (2013b) reported the syninclusion of the thermophilous ant Iridomyrmex geinitzi (Mayr, 1868) and temperate beraeid caddisflies Beraeodes pectinatus Ulmer, 1912 in a piece of Rovno amber. I. geintzi was transferred to the extinct genus Yantaromyrmex (Dlussky, Dubovikoff, 2013), which we consider here also as tropical (see above). Beraeodes is a West Palaearctic genus, comprised of a single extant species with a mostly northern distribution.

Yantaromyrmex geinitzi is a quite common species in Rovno and Baltic ambers, comprising 4-6\% of ant specimens in unbiased collections (Dlussky, Rasnitsyn, 2009), but only a few specimens of B. pectinatus are found there. Beraeodes dominates as $90 \%$ of caddisfly specimens in the late Eocene Bembridge Marls (Sukatsheva, 2014), where Oecophylla strongly dominates ants (Dlussky, Rasnitsyn, 2007; Dlussky, Perfilieva, 2014). The single extant Beraeodes species inhabits cold streams, the inflow to lakes, and other water bodies (Czachorowski, 1998; Corallini et al., 2015), where its larvae live on exposed underwater roots of plants along river banks and in lakes (Ivanov et al., 2001). This abundance of Beraeodes in the Bembridge Marls does not contradict the idea of periodic flooding of soils in these habitats where Oecophylla dominated. Interestingly, in one of the southernmost localities of extant Beraeodes, the MAT is the same as is estimated for the Bembridge Marls (Corallini et al., 2015).

The climate at the end of the early Eocene at Messel and middle Eocene at Eckfeld and the Oligocene in Sicily was much warmer than today with MAT estimated as $11-12{ }^{\circ} \mathrm{C}$ higher (Westerhold et al., 2020). Such a climate would have been quite suitable for Oecophylla, but too hot for Lasius and its obligate symbiotic aphids (Perkovsky, Wegierek, 2018 and references therein). The climate of Messel and Eckfeld would have been too hot for Beraeodes as well, with an estimated MAT at least $6{ }^{\circ} \mathrm{C}$ higher than in the warmest modern locality where Beraeodes was found. The Priabonian climate was probably more appropriate for Beraeodes: its syninclusion with ants are known from Rovno amber; at least seven Beraeodes specimens have been found from Baltic amber (Wichard, 2013; Perkovsky, 2013b). The Bembridge Marls has a single known locality, where two Oecophylla and two Beraeodes species are found (Dlussky, Perfilieva, 2014; Sukatsheva, 2014), suggesting a combination of climatic and environmental factors unknown anywhere else.

Some tropical elements of the Bembridge Marls fauna were very peculiar. For example, two specimens of the thermophilic subfamily Gumillinae (Neuroptera) have been found there (Perkovsky, Makarkin, 2020), the single locality of where Gumillinae has been found in the Cenozoic. This subfamily is represented today by only two species known by two specimens from northern South America (Martins et al., 2016). At the same time only one specimen of aberrant mastotermitid is known from Baltic amber, which is in a syninclusion with Liometopum (Engel et al., 2007), though size of the Ypresian and Miocene Mastotermes Froggatt, 1897 would not have prevented their being trapped in resins (Perkovsky, Vasilenko, 2020). That is, the abundance of Mastotermes in Bem- 
bridge ( $81 \%$ of all termites) (Jarzembowski, 1980) may indicate that winters there were milder in the Bembridge Marls forest than in the somewhat older Priabonian amber forests (Colombo et al., 2021, fig. 26).

MAT in the middle latitudes of the North America apparently decreased by $5-9{ }^{\circ} \mathrm{C}$ from the end of the Ypresian to the end of the Priabonian (Allen et al., 2020), while that of the latest Ypresian at Messel differs by $5{ }^{\circ} \mathrm{C}$ from that of Priabonian at Kučhlin (where Oecophylla is known) (Grein et al., 2011; Kvaček, Teodoridis, 2011), and differs by $9{ }^{\circ} \mathrm{C}$ from the Bembridge Marls (latest Priabonian).

The Bembridge flora in general is an analogue of Kučhlin's, but devoid of some thermophilic elements (Hayes, Collinson, 2014). The mostly temperate Palaearctic genus Beraeodes, which dominates at Bembridge, also could not have spread to Ukraine before the Priabonian.

Besides in European ambers and the Bembridge Marls, Oecophylla and Lasius coexisted in Radoboj (late Serravallian, middle Miocene) and Stavropol (Vishnevaya Balka, middle Miocene) (Dlussky, Putyatina, 2014; Perfilieva et al., 2017). Oecophylla are the most numerous ants in the Bembridge Marls assemblage with $69.8 \%$ of all ants identified to the genus level, in Radoboj Oecophylla obesa (Heer, 1849) it is $7.4 \%$, but Formica and Lasius taken together are $72 \%$ of all ants identified to genus (Dlussky, Putyatina, 2014). Oecophylla is also several times less abundant than Lasius in Stavropol (Dlussky, 1981a; Perfilieva et al., 2017). The coexistence of Oecophylla and Lasius appears possible when winters were mild and summers were not very hot, i.e. when the climate was equable. Since two Oecophylla species coexisted only in the Baltic and Bitterfeld amber forests and Bembridge, Priabonian climate seemed to provide opportunities for diversification of Oecophylla.

Both Oecophylla and Beraeodes dominated in the latest Eocene Bembridge Marls (Ross, Self, 2014) and Lasius was also common there (Dlussky, Perfilieva, 2014). The coexistence of Oecophylla with Beraeodes and Lasius was possible only in the equable Priabonian climate in both European ambers and Bembridge Marls.

LaPolla \& Greenwalt (2015) described the oldest named Lasius from the middle Eocene shale (Lutetian, 44-45 Ma, Dawson, Constenius (2018)) of Kishenehn Formation in northwestern Montana, USA based on two males, $1.3 \%$ of all determinable ants. The Kishenehn megaflora is moderately diverse, but dominated by the platanoid Macginitea augustiloba, which indicates a humid, subtropical paleoclimate (Dawson, Constenius, 2018). Oecophylla, the thermophile giant Formiciinae (dominant ants in Messel and Eckfeld, present in the terminal Ypresian Green River Formation), and Myrmeciinae (dominant ants in the Ypresian Mo-Clay, details of Eocene distribution in Radchenko, Perkovsky, 2020) are all absent in the Kishenehn Formation.

The Kishenehn Formation is interpreted as early Uintan (Uintan North American land mammal age: 41.3-46.2 Ma) based on twenty-six mammal taxa (Dawson, Constenius, 2018). Faunal diversity loss (the 'Bridgerian Crash') before the early Uintan is associated with climatic deterioration: relative mammalian abundance shifted from very diverse and evenly represented communities to those dominated by the condylarth Hyopsodus when regional MAT shifted from megathermal to a mesothermal $15^{\circ} \mathrm{C}$ and even lower (Woodburne et al., 2009). This is consistent with the presence of Lasius in this Lagerstätte.

Assignment of this species to Lasius raises certain doubts, however, as available specimens do not show a single clearly diagnostic feature of this genus. In addition, their heads appear to be suboval with barely marked occipital corners while the position of the hind coxae seems characteristic of the tribe Lasiini (op. cit., Fig. 8). We can only assume that Lasius glom LaPolla et Greenwalt, 2015 may represent a new, extinct genus, probably related to Lasius.

Some other insect taxa, e.g. Chrysopinae (Neuroptera, Chrysopidae) and Hybrizoninae (Hymenoptera, Ichneumonidae) also first appeared in Baltic amber and the Bembridge Marls (Makarkin, Perkovsky, 2020); in Baltic, Bitterfeld and Rovno amber; in the Bembridge Marls 
(Tolkanitz, Perkovsky, 2015); or are only known from European ambers of gymnosperm origin and the Bembridge Marls, e.g. Townesitinae (Hymenoptera, Ichneumonidae) (Tolkanitz, Perkovsky, 2018). Another important insect that first appeared in Baltic amber and the Bembridge Marls is the extant avian malaria vector Coquillettidia Dyar, 1905 (Culicidae), now represented in Europe by a single species (Szadziewski et al., 2019). The optimal biotope for Coquillettidia includes the larval host plants such as Typha sp., Phragmites sp., and Juncus sp.; the spread of semi-submerged helophytes appears to have been facilitated by the appearance of macrophyte lakes during Priabonian climatic cooling (Lyubarsky, Perkovsky, 2020 and references therein).

A Priabonian age for Bitterfeld and Baltic ambers is supported by the syninclusions of Oecophylla and Lasius, Temnothorax and Yantaromyrmex, and other tropical and Holarctic ant combinations mentioned above, as well as by the co-occurrence of various other insect taxa mentioned above that are also found in the confidently dated Bembridge Marls, and by the abundance of Baltic amber taxa unknown as compression fossils until Priabonian.

Thus, the coexistence of Oecophylla and Lasius in Europe was possible only from the late Eocene to the late Miocene: before this, the climate of European middle latitudes was too hot for aphids, the obligate symbionts of Lasius, but after the late Miocene it became too cold for Oecophylla. In general, the coexistence of Holarctic and tropical species on the same territory can be explained by the equable climate of the late Eocene, which has no analogues in modern times, except in limited areas in higher elevations of tropical mountains (Archibald, Farrell, 2003).

Acknowledgements. We are sincerely grateful to A.P. Rasnitsyn (Paleontological Institute, Moscow) for valuable comments and advice during preparation of the manuscript and for providing photographs of the Lasius-Oecophylla syninclusion; to V.D. Ivanov (St.-Petersburg University) for discussion of the ecology and biology of Beraeodes; to S.B. Archibald (Simon Fraser University, Burnaby, Canada) for improving English and comments on the ms; and to E.V. Martynova (Schmalhausen Institute of Zoology, Kiev) for photographs of the $L a$ sius-Oecophylla syninclusion. We are also grateful to K.S. Perfilieva (Moscow State University) whose suggestions considerably improved the original manuscript. This work was supported by the Grant NRFU No. 2010/02/0369 (for A.G. Radchenko).

\section{References}

Allen S.E., Lowe A.J., Peppe D.J., Meyer H.W. 2020. Paleoclimate and paleoecology of the latest Eocene Florissant flora (Central Colorado, USA) // Palaeogeography, Palaeoclimatology, Palaeoecology. Vol.551. Art.109678.

Archibald S.B., Farrell B.D. 2003. Wheeler's dilemma // Acta Zoologica Cracoviensia. Vol.46 (Supplement Fossil Insects). P.17-23.

Archibald S.B., Johnson K.R., Mathewes R.W., Greenwood D.R. 2011. Intercontinental dispersal of giant thermophilic ants across the Arctic during early Eocene hyperthermals // Proceedings of the Royal Society. Ser.B. Vol.278. P.3679-3688.

Bolton B. 1987. A review of the Solenopsis genus-group and revision of Afrotropical Monomorium Mayr // Bulletin of the British Museum (Natural History) (Entomology). Vol.54. No.3. P.263-452.

Bolton B. 2020. An online catalogue of the ants of the world // Available at: https://www.antcat.org/

Collingwood C.A. 1970. Formicidae from Nepal. Khumba Himal // Ergebnisse des Forschungsunternehmens Nepal Himalaya. Bd.3. S.371-387.

Colombo W.D., Perkovsky E.E., Waichert C., Azevedo C.O. 2021 (in press). Synopsis of the fossil flat wasps Epyrinae (Hymenoptera, Bethylidae), with description of three new genera and ten new species // Journal of Systematic Palaeontology.

Corallini C., Cianficconi F., Todini B. 2015. Trichopteran fauna of a hydrographic basin with a complex geological history (Umbria - Central Italy) // Annales de Limnologie - International Journal of Limnology. Vol.51. P.157-177.

Coty D., Aria C., Garrouste R. et al. 2014. The first anttermite syninclusion in amber with CT-scan analysis of taphonomy // PLoS ONE. Vol.9: e104410.

Crozier R.H., Newey P.S., Schlüns E.A., Robson S.K.A. 2010. A masterpiece of evolution - Oecophylla weaver ants (Hymenoptera: Formicidae) // Myrmecological News. Vol.13. P.57-71.

Czachorowski S. 1998. Chruściki (Trichoptera) jezior Polski - charakterystyka rozmieszczenia larw. Olsztyn: WSP Wyd. $156 \mathrm{~s}$.

Daley B. 1972. Some problems concerning the Early Tertiary climate of southern Britain // Paleogeogra- 
phy, Paleoclimatology, Paleoecology. Vol.11. Iss.3. P.177-190.

Dawson M.R., Constenius K.N. 2018. Mammalian Fauna of the Middle Eocene Kishenehn Formation, Middle Fork of the Flathead River, Montana // Annals of Carnegie Museum. Vol.85. No.1. P.25-60.

Deichmüller J.V. 1881. Fossile Insecten aus dem Diatomeenschiefer von Kutschlin bei Bilin, Böhmen // Nova Acta Academiae Caesareae Leopoldino-Carolinae Germanicae Naturae Curiosorum. Bd.42. No.6. S.293-330.

Demchenko A.V. 1975. [Multispecies associations of ants in spruce forests of the Moscow region] // Murav'i i zashchita lesa: Materialy 5-go Vsesoyuznogo simposiuma. Moskva. P.77-81 [in Russian].

Dlussky G.M. 1965. [Protected territory on ants] // Zhurnal obshchei biologii. T.26. Vyp.4. P.479-489 [in Russian].

Dlussky G.M. 1981a. [Miocene ants (Hymenoptera, Formicidae) of the USSR] // V.N. Vishnyakova, G.M. Dlussky, L.N. Pritykina. Novye iskopaemye nasekomye s territorii SSSR. Trudy Paleontologicheskogo Instituta. T.183. P.64-83 [in Russian].

Dlussky G.M. 1981b. [Ants of deserts]. Moscow: Nauka. 230 p. [In Russian]

Dlussky G.M. 2008. [Ants of the tribe Formicini (Hymenoptera, Formicidae) from Late Eocene amber of Europe] // Paleontologicheskii Zhurnal. No.5. P.4559 [in Russian; English translation: Paleontological Journal. Vol.42. No.5. P.500-513].

Dlussky G.M. 2009. The ant subfamilies Ponerinae, Cerapachyinae, and Pseudomyrmecinae (Hymenoptera, Formicidae) in the Late Eocene ambers of Europe // Paleontological Journal. Vol.43. No.9. P.1043-1086.

Dlussky G.M. 2010. [Ants of the genus Plagiolepis Mayr (Hymenoptera, Formicidae) from Late Eocene ambers of Europe]// Paleontologicheskii Zhurnal. No.5. P.6473 [in Russian; English translation: Paleontological Journal. Vol.44. No.5. P.546-555].

Dlussky G.M. 2011. The ants of the genus Lasius Fabricius from the Late Eocene European Ambers // Vestnik zoologii. Vol.45. No.3. P.209-222.

Dlussky G.M. 2012. [New fossil ants of the subfamily Myrmeciinae from Germany] // Paleontologicheskii Zhurnal. No.3. P.65-69 [in Russian; English translation: Paleontological Journal. Vol.46. No.3. P.288292].

Dlussky G.M., Dubovikoff D.A. 2013. Yantaromyrmex gen. n. - a new ant genus (Hymenoptera: Formicidae) from Late Eocene ambers of Europe // Caucasian Entomological Bulletin. Vol.9. No.2. P.305-314.

Dlussky G.M., Perfilieva K.S. 2014. Superfamily Formicoidea Latreille, 1802 // A.V. Antropov, S.A. Belokobylskij, S.G. Compton et al. The wasps, bees and ants from the Insect Limestone (Late Eocene) of the Isle of Wight, U.K. Earth and Environmental Science Transactions of the Royal Society of Edinburgh. Vol.104. Iss.3-4. P.410-438.

Dlussky G.M., Perkovsky E.E. 2002. [Ants (Hymenoptera, Formicidae) from Rovno amber] // Vestnik zoologii. T.35. No.5. P.3-20 [in Russian].
Dlussky G.M., Putyatina T.S. 2014. Early Miocene ants (Hymenoptera, Formicidae) from Radoboj, Croatia // Neues Jahrbuch für Geologie und Paläontologie Abhandlungen. Bd.272. H.3. P.237-285.

Dlussky G.M., Rasnitsyn A.P. 2007. [Paleontological record and stages of ants evolution] // Uspekhi sovremennoi biologii. T.127. No.2. P.118-134 [in Russian]

Dlussky G.M., Rasnitsyn A.P. 2009. Ants (Insecta: Vespida: Formicidae) in the Upper Eocene amber of Central and Eastern Europe // Paleontological Journal. Vol.43. No.9. P.1024-1042.

Dlussky G.M., Wappler T., Wedmann S. 2008. New middle Eocene formicid species from Germany and the evolution of weaver ants // Acta Palaeontologica Polonica. Vol.53. No.4. P.615-626.

Dlussky G.M., Wappler T., Wedmann S. 2009. Fossil ants of the genus Gesomyrmex Mayr from the Eocene of Europe and remarks on the evolution of arboreal ant communities // Zootaxa. Vol.2031. P.1-20.

Dlussky G.M., Wedmann S. 2012. The poneromorph ants of Grube Messel, Germany: high biodiversity in the Eocene// Journal of Systematic Palaeontology. Vol.10. Iss.4. P.725-753.

DubovikoffD.A. 2012. Dolichoderinae ants (Hymenoptera: Formicidae) of the European late Eocene ambers and its relation with modern fauna // Recursos Naturales. P.166-178.

Dubovikoff D.A., Dlussky G.M., Perkovsky E.E., Abakumov E.V. 2020. [A new species of the genus Protaneuretus Wheeler (Hymenoptera, Formicidae) from Bitterfeld amber (late Eocene) with species key of the genus] // Paleontologicheskii Zhurnal. No.4. P.67-69 [in Russian; English translation: Paleontological Journal. Vol.54. No.4. P.389-391].

Emery C. 1891. Le formiche dell'ambra Siciliana nel Museo Mineralogico dell'Università di Bologna // Memorie della Reale Accademia delle Scienze dell'Istituto di Bologna. T.5. No.1. P.141-165.

Engel M.S., Grimaldi D.A., Krishna K. 2007. A synopsis of Baltic amber termites (Isoptera) // Stuttgarter Beitrage zur Naturkunde, Serie B, Geologie und Paläontologie. Vol.372. P.1-20.

Grein M., Utescher T., Wilde V., Roth-Nebelsick A. 2011. Reconstruction of the middle Eocene climate of Messel using palaeobotanical data // Neues Jahrbuch für Geologie und Paläontologie - Abhandlungen. Bd.260. H.3. P.305-318.

Hayes P.A., Collinson M.E. 2014. The Flora of the Insect Limestone (latest Eocene) from the Isle of Wight, southern England // Earth and Environmental Science Transactions of the Royal Society of Edinburgh. Vol.104. No.3-4. P.245-261.

Hölldobler B. 1983. Territorial behavior in the green tree ant (Oecophylla smaragdina) // Biotropica. Vol.15. No.4. P.241-250.

Hooker J.J. 1994. Mammalian taphonomy and palaeoecology of the Bembridge Limestone Formation (Late Eocene, S. England) // Historical Biology. Vol.8. Iss.1-4. P.49-69. 
Hooker J.J., Grimes S., Mattey D., Collinson M.E., Sheldon N.D. 2009. Refined correlation of the UK Late Eocene-Early Oligocene Solent Group and timing of its climate history // C. Koeberl, A. Montanari (eds). The Late Eocene Earth - hothouse, icehouse, and impacts. Geological Society of America. Special Paper 452. P.179-195.

Ivanov V.D., Grigorenko V.N., Arefina T.I. 2001. [The Order Trichoptera] // S.Ya. Tsalolikhin (ed.). Opredelitel presnovodnyh bespozvonochnyh Rossii i sopredelnyh territorij. T.5. Vysshye nasekomye. St.Petersburg: Nauka Publ. P.7-72, 388-455 [in Russian].

Jarzembowski E.A. 1980. Fossil insects from the Bembridge Marls, Palaeogene of the Isle of Wight, Southern England // Bulletin of the British Museum (Natural History), Geology Series. Vol.33. No.4. P.237-293.

Jessen K. 2020. New fossil ants of the subfamily Myrmicinae (Hymenoptera, Formicidae) from the Upper Oligocene of Enspel (Westerwald Mountains, Rhineland Palatinate, Germany) // Palaeobiodiversity and Palaeoenvironments. Vol.100. P.1007-1045.

Kaasalainen U., Schmidt A.R., Rikkinen J. 2017. Diversity and ecological adaptations in Paleogene lichens // Nature Plants. Vol.3. Art.17049.

Kallal R.J., LaPolla J.S. 2012. Monograph of Nylanderia of the world, Part 2: Nylanderia in the Nearctic // Zootaxa. Vol.3508. P.1-64.

Koteja J. 1989. Syninclusions // Wrostek. No.8. S.7-8.

Kutscher M., Koteja J. 2000. Coccids and aphids (Hemiptera: Coccinea, Aphidinea), prey of ants (Hymenoptera, Formicidae): evidence from Bitterfeld amber // Polskie Pismo Entomologiczne. T.69. No.2. P.179-185.

Kvaček Z., Teodoridis V. 2011. The Late Eocene flora of Kučlín near Bílina in North Bohemia revisited // Acta Musei Nationalis Pragae, Series B - Historia Naturalis. Vol.67. No.3-4. P.83-144.

LaPolla J.S., Brady S.G., Shattuck S.O. 2010. Phylogeny and taxonomy of the Prenolepis genus-group of ants // Systematic Entomology. Vol.35. P.118-131.

LaPolla J.S., Dlussky G.M. 2010. Review of fossil Prenolepis genus-group species // Proceedings of the Entomological Society of Washington. Vol.112. No.2. P.258-273.

LaPolla J.S., Greenwalt D.E. 2015. Fossil Ants (Hymenoptera: Formicidae) of the Middle Eocene Kishenehn Formation // Sociobiology. Vol.62. P.163-174.

Lokkers C. 1990. Colony dynamics of the green tree ant (Oecophylla smaragdina Fab.) in a seasonal tropical climate. PhD 69 thesis. Townsville, Queensland: James Cook University of North Queensland. 301 p.

Lyubarsky G.Yu., Perkovsky E.E. 2020. First Rovno amber species of the genus Telmatophilus (Coleoptera: Clavicornia: Cryptophagidae) from Veselukha floodplain // Invertebrate Zoology. Vol.17. No.1. P.25-35.

Makarkin V.N., Perkovsky E.E. 2020. A new species of Proneuronema (Neuroptera: Hemerobiidae) from late Eocene Rovno amber // Zootaxa. Vol.4718. No.2. P.292-300.
Martins C.C., Ardila-Camacho A., Aspöck U. 2016. Neotropical osmylids (Neuroptera, Osmylidae): Three new species of Isostenosmylus Krüger, 1913, new distributional records, redescriptions, checklist and key for the Neotropical species // Zootaxa. Vol.4149. P.1166.

Mayr G. 1868. Die Ameisen des baltischen Bernsteins // Beiträge zur Naturkunde Preussens. Königlichen Physikalisch-Ökonomischen Gesellschaft zu Königsberg. Bd.1. S.1-102.

Messer S.J., Cover S.P., LaPolla J.S. 2016. Nylanderia deceptrix sp.n., a new species of obligately socially parasitic formicine ant // ZooKeys. Vol.552. P.49-65.

Ollier C.D., Pain C.F. 2019. Neotectonic mountain uplift and geomorphology // Geomorphologia. No.4. P.4 25.

Perfilieva K.S., Dubovikoff D.A., Dlussky G.M. 2017. [Miocene ants (Hymenoptera, Formicidae) from Crimea] // Paleontologicheskii Zhurnal. No.4. P.5464 [in Russian; English translation: Paleontological Journal. Vol.51. No. 4. P.391-401].

Perkovsky E.E. 2006. [Occurrence of ant (Hymenoptera, Formicidae) and aphid (Homoptera, Aphidinea) syninclusions in Saxonian and Rovno ambers] // Paleontologicheskii Zhurnal. No.2. P.190-192 [in Russian; English translation: Paleontological Journal. Vol.40. No.2. P.190-192].

Perkovsky E.E. 2007a. [Syninclusions of ants Lasius schiefferdeckeri (Hymenoptera, Formicidae) and aphids Germaraphis (Homoptera, Aphidinea) in Rovno and Saxonian ambers] // Vestnik zoologii. Vol.41. No.2. P.181-185 [in Russian].

Perkovsky E.E. 2007b. First occurrence of syninclusion of ant Ctenobethylus goepperti (Mayr) (Hymenoptera, Formicidae) and matsucoccid (Homoptera, Matsucoccidae) in Rovno amber // Russian Entomological Journal. Vol.15. No.4. P.419-420.

Perkovsky E.E. 2008a. First occurrence of syninclusion of ants Lasius schiefferdeckeri Mayr (Hymenoptera, Formicidae) and aphids Germaraphis ungulata Heie (Homoptera, Aphidinea) in amber (Klesov) // Russian Entomological Journal. Vol.17. No.2. P.207-208.

Perkovsky E.E. 2008b. [First finding of syninclusion of ants Lasius schiefferdeckeri (Hymenoptera, Formicidae) and aphids Germaraphis (Homoptera, Aphidinea) in Baltic amber] // Vestnik zoologii. Vol.50. No.2. P.180 [in Russian].

Perkovsky E.E. 2009a. On finding a single-clawed aphid, Germaraphis ungulata (Homoptera, Aphidinea), in a syninclusion with the ant Monomorium mayrianum (Hymenoptera, Formicidae) in the Saxonian amber // Paleontological Journal. Vol.43. No.9. P.1006-1007.

Perkovsky E.E. 2009b. Differences in ant (Hymenoptera, Formicidae) species composition between weight fractions of Rovno Amber // Paleontological Journal. Vol.43. No.9. P.1087-1091.

Perkovsky E.E. 2010. [Participation of Germaraphis aphids (Homoptera, Aphidinea) in weight fractions of the Rovno amber and their syninclusions with ants] // Vestnik zoologii. Vol.44. No.1. P.55-62 [in Russian]. 
Perkovsky E.E. 2011a. Syninclusions of the Eocene winter ant Prenolepis henshei (Hymenoptera: Formicidae) and Germaraphis aphids (Hemiptera: Eriosomatidae) in Late Eocene Baltic and Rovno amber: some implications // Russian Entomological Journal. Vol.20. No.3. P.303-313.

Perkovsky E.E. 2011b. [First finding of syninclusion of ants Formica sp. (Hymenoptera, Formicidae) and aphids Electrocallis (Homoptera, Aphidinea, Drepanosiphidae) in Late Eocene amber from west coast of Jutland] // Vestnik zoologii. Vol.45. No.5. P.438 [in Russian].

Perkovsky E.E. 2013a. [First finding of syninclusions of Dolichoderus ants (Hymenoptera, Formicidae) and aphids (Hemiptera, Aphidinea) in late Eocene Baltic amber] // Vestnik zoologii. Vol.47. No.4. P.308 [in Russian].

Perkovsky E.E. 2013b. [First find of unique syninclusion of Beraeidae (Trichoptera) and thermophilous ants Iridomyrmex geinitzi (Formicidae) in Rovno Amber] // Vestnik zoologii. Vol.47. No.6. P.564 [in Russian].

Perkovsky E.E. 2016. Tropical and Holarctic ants in Late Eocene ambers // Vestnik zoologii. Vol.50. No.2. P.111-122.

Perkovsky E.E. 2017. Comparison of biting midges of the Early Eocene Cambay amber (India) and Late Eocene European ambers supports the independent origin of European ambers // Vestnik zoologii. Vol.51. No.4. P.275-284.

Perkovsky E.E., Makarkin V.N. 2020. A new species of Sympherobius Banks (Neuroptera: Hemerobiidae) from the late Eocene Rovno amber // Palaeoentomology. Vol.3. No.2. P.196-203.

Perkovsky E.E., Rasnitsyn A.P., Vlaskin A.P., Rasnitsyn S.P. 2010. Community structure in the amber forest: study of the arthropod syninclusia in the Rovno amber (Late Eocene of Ukraine) // Acta Geologica Sinica, English Edition. Vol.84. P.954-958.

Perkovsky E.E., Rasnitsyn A.P., Vlaskin A.P., Rasnitsyn S.P. 2012. [Contribution to the study of the structure of amber forest communities based on analysis of syninclusions in the Rovno Amber (Late Eocene of Ukraine)] // Paleontologicheskii Zhurnal. No.3. P.70 78 [in Russian; English translation: Paleontological Journal. Vol.46. P.293-301].

Perkovsky E.E., Rasnitsyn A.P., Vlaskin A.P., Taraschuk M.V. 2007. A comparative analysis of the Baltic and Rovno amber arthropod faunas: representative samples // African Invertebrates. Vol.48. No.1. P.229245.

Perkovsky E.E., Vasilenko D.V. 2020. Evolution of tropical termites in early Paleogene with description of a new species of Stylotermitidae (Isoptera) from Rovno amber (late Eocene of Ukraine) // Invertebrate Zoology. Vol.17. No.3. P.205-218.

Perkovsky E., Wegierek P. 2018. Aphid-Buchnera-Ant symbiosis; or why are aphids rare in the tropics and very rare further south? // Earth and Environmental Science. Transactions of the Royal Society of Edinburgh. Vol.107. No.2-3. P.297-310.
Perrichot V., Girard V. 2009. A unique piece of amber and the complexity of ancient forest ecosystems // Palaios. Vol.24. No.3. P.137-139.

Pisarski B. 1960. Dwa nowe gatunki z rodzaju Paratrechina Motschulsky // Annales Zoologici. T.18. No.19. P.349-356.

Prebus M. 2015. Palearctic elements in the old world tropics: a taxonomic revision of the ant genus Temnothorax Mayr (Hymenoptera, Formicidae) for the Afrotropical biogeographical region // ZooKeys. Vol.483. P.23-57.

Prebus M. 2017. Insights into the evolution, biogeography and natural history of the acorn ants, genus Temnotho$\operatorname{rax}$ Mayr (Hymenoptera: Formicidae) // BMC Evolutionary Biology. Vol.17. No.250. P.1-22.

Radchenko A.G. 2016. [The ants (Hymenoptera, Formicidae) of Ukraine]. Kiev. 497 pp. [In Russian]

Radchenko A.G., Dlussky G.M. 2016. Further data on the extinct ant genus Eocenomyrma (Hymenoptera, Formicidae) // Vestnik zoologii. Vol.50. No.5. P.395406.

Radchenko A.G., Perkovsky E.E. 2009. Monomorium kugleri n.sp., a new fossil ant species (Hymenoptera, Formicidae, Myrmicinae) from the late Eocene Rovno Amber (Ukraine) // Israel Journal of Entomology. Vol.39. P.99-103.

Radchenko A.G., Perkovsky E.E. 2016. The ant Aphaenogaster dlusskyana sp.nov. (Hymenoptera, Formicidae) from the Sakhalin amber - the earliest described species of an extant genus of Myrmicinae // Paleontological Journal. Vol.50. No.9. P.936-946.

Radchenko A.G., Perkovsky E.E. 2020. [New records of the fossil ant genus Prionomyrmex Mayr (Hymenoptera, Formicidae, Myrmeciinae) from Late Eocene European ambers] // Paleontologicheskii Zhurnal. No.6. P.60-67 [in Russian; English translation: Paleontological Journal. Vol.54. No.6. P.617-626].

Reznikova Zh.I. 1983. [Interspecific relations in ants]. Novosibirsk: Nauka Publ. 206 pp. [In Russian]

Ross A.J., Self A. 2014. The fauna and flora of the Insect Limestone (late Eocene), Isle of Wight, UK: introduction, history and Geology // Earth and Environmental Science Transactions of the Royal Society of Edinburgh. Vol.104. No.3-4. P.233-244.

Sadowski E.M., Seyfullah L.J., Schmidt A.R., Kunzmann L. 2017. Conifers of the 'Baltic amber forest' and their palaeoecological significance // Stapfia. Vol.106. P.173.

Schmidt C.A., Shattuck S.O. 2014. The higher classification of the ant subfamily Ponerinae (Hymenoptera: Formicidae), with a review of ponerine ecology and behavior // Zootaxa. Vol.3817. No.1. P.1-242.

Segev U., Ziv Y. 2012. Consequences of behavioral vs. numerical dominance on foraging activity of desert seed-eating ants // Behavioral Ecology and Sociobiology. Vol.66. P.623-632.

Seifert B. 2020. A taxonomic revision of the Palaearctic members of the subgenus Lasius s.str. (Hymenoptera, Formicidae) // Soil organisms. Vol.92. No.1. P.1586. 
Sontag E. 2003. Animal inclusions in a sample of unselected Baltic amber// Acta zoologica cracoviensia. Vol.46 (Suppl. - Fossil Insects). P.431-440.

Stukalyuk S.V. 2015. [Structure of the ant assemblages (Hymenoptera, Formicidae) in the broad-leaf forests of Kiev]//Entomologicheskoe obozrenie. T.94. Vyp.1. P.67-89 [in Russian].

Stukalyuk S.V. 2017. [Interactions of three dominant ant species, Lasius emarginatus (O1.), Formica rufa L., and Lasius fuliginosus (Latr.) (Hymenoptera, Formicidae) among themselves and with subordinate species in broadleaf forests. Communication 1] // Entomologicheskoe obozrenie. T.96. Vyp.3. P.451-478 [in Russian].

Sukatsheva I.D. 2014. Caddis-flies (Insecta: Trichoptera) from the Insect Limestone (Bembridge Marls, Late Eocene) of the Isle of Wight, UK // Earth and Environmental Science. Transactions of the Royal Society of Edinburgh. Vol.104. No.3-4. P.327-333.

Supriya K., Price T.D., Moreau C.S. 2020. Competition with insectivorous ants as a contributor to low songbird diversity at low elevations in the eastern Himalaya // Ecology and Evolution. Vol.10. Is.10. P.4280 4290 .

Szadziewski R., Sontag E., Szwedo J. 2019. Mosquitoes of the extant avian malaria vector Coquillettidia Dyar, 1905 from Eocene Baltic amber (Diptera: Culicidae) // Palaeoentomology. Vol.2. No.6. P.650-656.

Théobald N. 1937. Les Insectes Fossiles des Terrains Oligocènes de France. Nancy. 473 p.

Tolkanitz V.I., Perkovsky E.E. 2015. [A new species of the genus Paxylommites (Hymenoptera, Ichneumonidae, Hybrizoninae) from Baltic amber] // Paleontologicheskii Zhurnal. No.4. P.55-57 [in Russian; English translation: 2018. Paleontological Journal. Vol.49. No.4. P.391-393].

Tolkanitz V.I., Perkovsky E.E. 2018. [First record of the Late Eocene ichneumon fly Rasnitsynites tarsalis Kasparyan (Ichneumonidae, Townesitinae) in Ukraine confirms correlation of the Upper Eocene Lagerstatten] // Paleontologicheskii Zhurnal. No.1. P.29-31 [in
Russian; English translation: 2018. Paleontological Journal. Vol.52. No.1. P.31-34].

Vepsäläinen K., Pisarski B. 1982. Assembly of island ant communities // Annales Zoologici Fennici. Vol.19. P.327-335.

Wappler T. 2003. Systematik, Phylogenie, Taphonomie und Paläökologie der Insekten aus dem Mittel-Eozän des Eckfelder Maares, Vulkaneifel. Dissertation zur Erlangung des Grades eines Doktors der Naturwissenschaften. Mathematisch-Naturwissenschaftlichen Fakultät der Technischen Universität Clausthal. 240 S. +18 Tafel.

Weitschat W. 2009. Jäger, Gejagte, Parasiten und blinde Passagiere - Momentaufnahmen aus dem Bernsteinwald // Denisia. Vol.26. P.243-256.

Westerhold T., Marwan N., Drury A.J. et al. 2020. An astronomically dated record of Earth's climate and its predictability over the last 66 million years // Science. No.369. P.1383-1387.

Wetterer J.K. 2017. Geographic distribution of the weaver ant Oecophylla smaragdina // Asian myrmecology. Vol.9. P.1-12.

Wheeler W.M. 1910. Ants, their structure, development and behaviour. Columbia University Biological Series 9. New York. 663 p.

Wheeler W.M. 1915. The ants of the Baltic Amber // Schriften der Physikalisch-Ökonomischen Gesellschaft zu Königsberg in Preußen. Bd.55. H.2. P.1-142.

Wichard W. 2009. Taphozönosen im Baltischen Bernstein // Denisia. Vol.26. S.257-266.

Wichard W. 2013. Overview and descriptions of Trichoptera in Baltic amber: Spicipalpia and Integripalpia. Berlin: Museum für Naturkunde Publ. 230 p.

Woodburne M.O., Gunnell G.F., Stucky R.K. 2009. Climate directly influences Eocene mammal faunal dynamics in North America // Proceedings of the National Academy of Sciences of the United States of America. Vol.106. No.32. P.13399-13403.

Zakharov A.A. 1991. [Organization of ants' communities]. Moscow: Nauka Publ. 277 pp. [In Russian]

Responsible editor K.G. Mikhailov 